\title{
THE INCREASING HARMONIC EFFECTS OF SSPWM MULTILEVEL INVERTER CONTROLLING LOAD CURRENTS INVESTIGATED ON MODULATION INDEX
}

\author{
Erol Can, H. Hüseyin Sayan
}

Original scientific paper Step sinus pulse width modulation (SSPWM) multilevel inverter is designed in order to control loads with reducing nonlinear effects as harmonics. Multilevel inverter has six switches for every phase and the switches are connected to control inputs and outputs of load. This method focuses on the identification of twelve IGBT and six MOSFET switches as nonlinear device, which consists of only the active and passive switches in three phase multilevel inverter. Inverter switches operate with pulse width modulation after signals of six step sinus compare with 2- small triangle signals for every phase. While operating characteristics of the switches are determined, a mathematical model of inverter controlling loads can be formed. After that, two PWM techniques are used to investigate the non-linear effects on this circuit model which contains mixed switches in its structure. So, the inverter load of ohmic $(R)$ and inductive $(L)$ are performed at the simulation so that performance of SSPWM multilevel inverter could be showed on loads. So, SSPWM and SPWM controlling inverter is tested on frequencies and modulation indexes. Then, performances of SPWM inverter and SSPWM multilevel inverter running loads are compared with output results.

Keywords: inverter; nonlinear effects; mixed switches; step-sinus pulse width modulation

\section{Pojačavajući učinci harmonika SSPWM višerazinskog izmjenjivača u reguliranju struja opterećenja istraživanih na indeksu modulacije}

Izvorni znanstveni članak Višerazinski izmjenjivač step sinus pulse width modulation (SSPWM) dizajniran je za reguliranje opterećenja s reducirajućim nelinearnim učincima kao harmonike. Višerazinski izmjenjivač ima šest prekidača za svaku fazu a prekidači su povezani u reguliranju ulaznih i izlaznih opterećenja. Ova je metoda usmjerena na identifikaciju dvanaest IGBT i šest MOSFET prekidača kao nelinearnog uređaja koji se sastoje samo od aktivnih i pasivnih prekidača u trofaznom višerazinskom izmjenjivaču. Prekidači izmjenjivača rade uz modulaciju širine impulsa nakon što se signali six step sinus usporede s dva mala trokutasta signala za svaku fazu. Kad se odrede radne karakteristike prekidača, može se uspostaviti matematički model izmjenjivača za reguliranje opterećenja. Nakon toga, pomoću dva načina modulacije širine impulsa (PWM) istražuju se nelinearni učinci na takav model strujnog kruga koji ima miješane prekidače. Simulira se omsko $(R)$ i induktivno $(L)$ opterećenje kako da bi se izvedba SSPWM višerazinskog pretvarača mogla pokazti na opterećenjima. Tako se testiraju frekvencije i indeksi modulacije izmjenjivača reguliranog s SSPWM i SPWM. Zatim se rezultati radnih opterećenja SPWM izmjenjivača i SSPWM višerazinskog izmjenjivača uspoređuju s izlaznim rezultatima.

Ključne riječi: izmjenjivač; korak-modulacija širine sinus impulsa; miješani prekidači; nelinearni učinci

\section{Introduction}

Converters and inverter applications are very popular nowadays to supply energy and increase their quality. [1, 2]. Power electronic circuits are the most frequently used for energy conversion methods on circuit control. Therefore the circuits were investigated in articles $[1 \div 3]$. However, the implementation of some PWM techniques for the three-phase electric motor and ohmic $(R)$ and inductive $(L)$ loads drivers has some difficulties and constraints in its structure [8]. While three-phase inverters generate a waveform of fundamental with pulse-width modulation (PWM), they cause a harmonics because of having nonlinear switches as IGBTs and MOSFETs $[3 \div 5]$. In addition, if the number of switches and PWMs has increased on the inverter, nonlinear effect and distortions increase on load currents and voltages. Some studies are presented so that nonlinear effect can be reduced on PWM inverters running loads $[6,7]$. In the study, twelve IGBT switches of three phase inverter are connected to inputs of three phase load while six MOSFETs are connected to outputs of three phase load for investigating the nonlinear effect caused by the hybrid switching system. While operating characteristics of the switches are designed according to step sinus modulation developed for multilevel inverter, mathematical equations are calculated for total alternating voltages on load. Mathematical model created with step sinus pulse width modulation (SSPWM) on multilevel inverter unlike other studies is published $[10 \div 14]$ because a large number of mixed semiconductor switches are operated on one device at the same time and switches are controlled with SSPWM generated by the steps comparing with triangles as shown in Fig. 2. According to resource levels, SSPWM duty cycle can be controlled with the modulation method for example as (5a, 7a, 9a, 11a, 13a) and (10a, 14a, 18a, 22a, 26a) shown in Fig. 2a. For each phase, six step sinus signals and two small triangular signals must be compared. New mathematical equations are created with SSPWM on ohmic $(R)$ and inductive $(L)$ loads for multilevel inverter. The proposed model is built in Matlab Simulink in order to test the performance. After system of simulation, SSPWM multilevel inverter is compared with traditional PWM inverter when analysing results. According to observed simulations, demanded results are achieved because there are low harmonic distortion and high performance on load currents while SSPWM multilevel inverter is controlling $R$ and $L$ loads. In addition, SSPWM multi-level inverter with split direct forward sources has achieved to obtain better results than traditional PWM inverter although the circuit has more and mixed power switches.

\section{Three-phase multilevel inverter}

Fig. 1 demonstrates three-phase multilevel inverter. The ohmic loads of circuit are as $R_{a}, R_{b}$ and $R_{c} . L_{a}, L_{b}$ and $L_{c}$ are inductors. $i_{a}, i_{b}$ and $i_{c}$ are the phase currents on the 
inverter. $Z_{a}, Z_{b}$ and $Z_{c}$ are impedances for every phase. $V d c$ is the DC voltage, system source is provided by the DC voltage source. S0-S5 are the MOSFET switches. A new model of three phase inverter circuit model is built for SSPWM method providing new mathematical model shown in Fig. 1. $Z_{a}=R_{a}+j X L_{a}, Z_{b}=R_{b}+j X L_{b}, Z_{c}=R_{c}$ $+j X L_{c}$.

\section{Pulse width modulation (SSPWM) for multi-level inverter}

Pulse width modulation technique is considered in

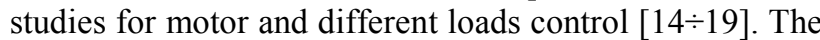
step sinus pulse width modulation technique is handled for the multi-level inverter topology in Fig. 2. SSPWM is formed when six step sinus signals on different electrical angles are compared with two small triangles. Sinus signal has steps that increase $b$ unit lengths on vertical and different unit lengths on horizontal as shown in Fig. 2. Interactions of steps with triangles form similar triangles. Every formed triangle has a different size in all formed triangles. So, pulse widths which are switching time can be obtained with similar triangles on half period $(T / 2)$ while considering dc voltage sources level. $D_{f}$ is first pulse width for switching time, $D_{a}$ is average pulse width for switching time, $n$ is sampling number.

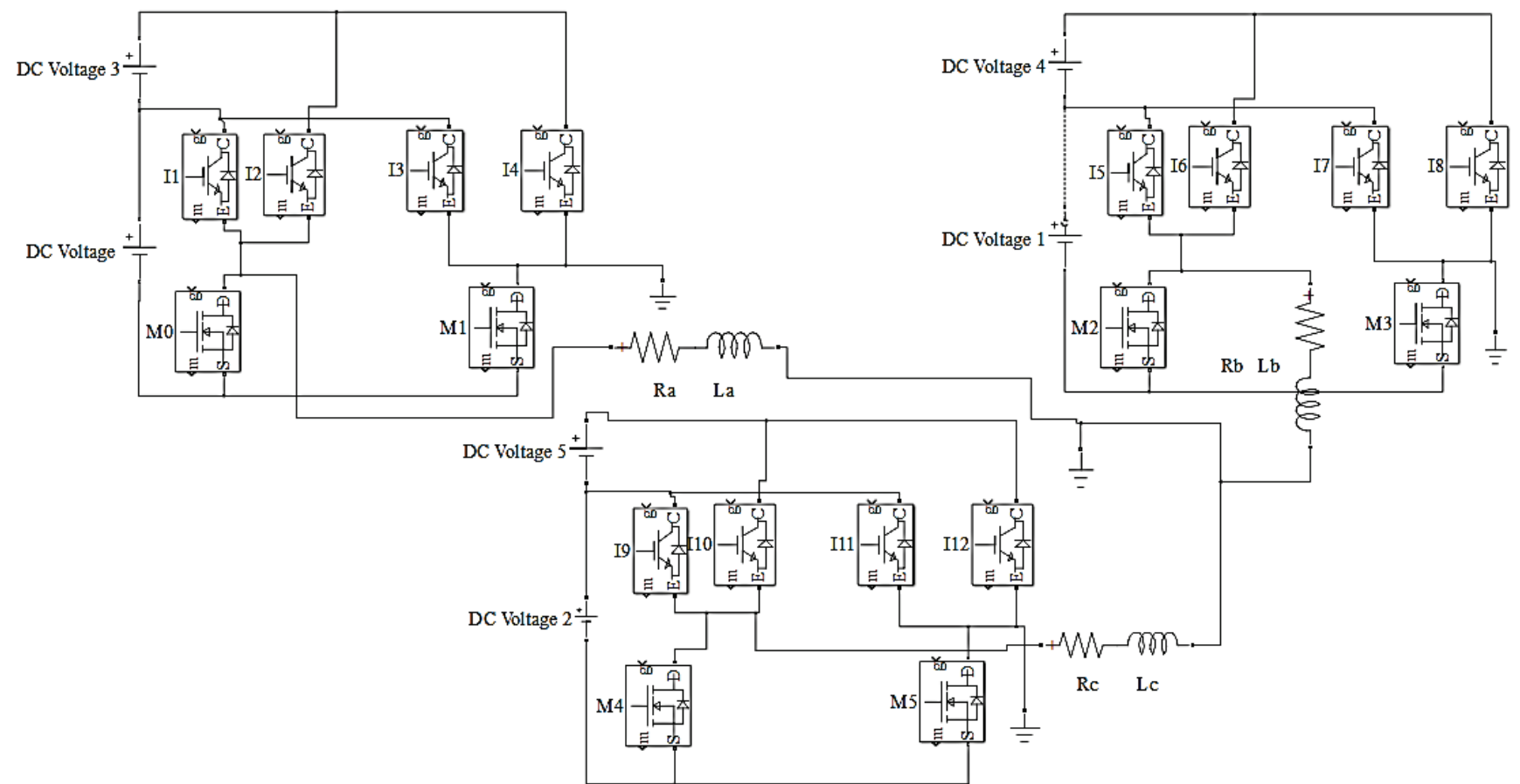

Figure 1 Three phase multilevel inverter

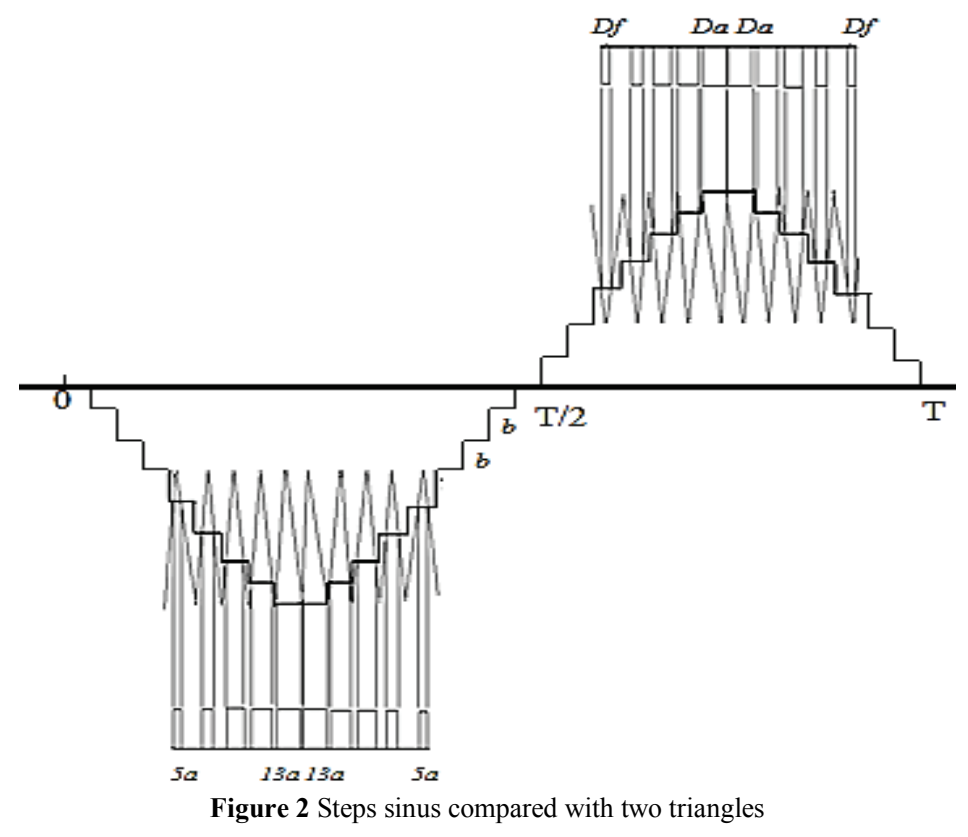

SSPWM producing current behaviour with equation is given in Fig. 3.
The size changes of the SSPWMs are linear in period of $T / 2$ as shown in Fig. 4. 
There are two parts on first level while a direct voltage source is activated. $i_{f i s}$ value of produced total current for first level as in Eq. (1).

$$
2 \times 2\left(i_{1}+i_{2}+\ldots+i_{n / 2}\right)=i_{f}
$$

and

$2 \times 2\left(\frac{\mathrm{d} i_{1}}{\mathrm{~d} t_{1}}+\frac{\mathrm{d} i_{2}}{\mathrm{~d} t_{2}}+\ldots+\frac{\mathrm{d} i_{n / 2}}{\mathrm{~d} t_{n / 2}}\right)=\frac{\mathrm{d} i_{f}}{\mathrm{~d} t_{f}}$

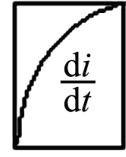

(a)

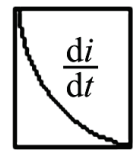

(b)
Figure 3 (a) PWM for positive period of current from $T$ to $T / 2$, (b) PWM for negative period of current from 0 to $T / 2$

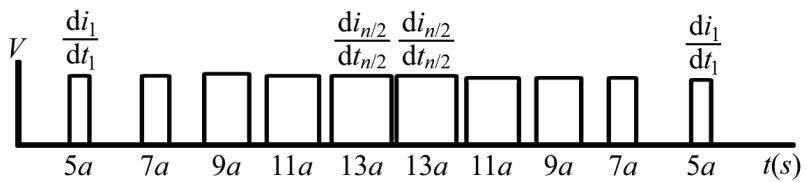

Figure $4 \mathrm{~A}$ linear increase of the PWM signals according to first level source

There is one part on second level while two $d c$ sources operate on inverter $i_{f}$ is value of produced total current for second level as in Eq. (2).

$4\left(i_{1}+i_{2}+\ldots+i_{n / 2}\right)=i_{f}$

and

$4\left(\frac{\mathrm{d} i_{1}}{\mathrm{~d} t_{1}}+\frac{\mathrm{d} i_{2}}{\mathrm{~d} t_{2}}+\ldots+\frac{\mathrm{d} i_{n / 2}}{\mathrm{~d} t_{n / 2}}\right)=\frac{\mathrm{d} i_{S}}{\mathrm{~d} t_{S}}$

Equation of total current is obtained for $T / 2$ as Eq. (3).

$i=i_{f}+i_{S}$ and $\frac{\mathrm{d} i}{\mathrm{~d} t}=\frac{\mathrm{d} i_{S}}{\mathrm{~d} t_{S}}+\frac{\mathrm{d} i_{f}}{\mathrm{~d} t_{f}}$

When pulse widths produced create total alternating voltage by step sinus pulse widths modulation on period of $T / 2$, Pulse widths increase from $D_{f}$ to $D_{a}$. The increases can be estimated because similar triangle rules provide full numerical value as Fig. 2 . There are $2 n$ pulse widths for first level on period of $T / 2$. There is $n$ pulse width for second level on period of $T / 2$. Pulse widths are added as in Eq. (4). So, $3 n$ pulse width is available. But, $4 n$ will be used for the alternating voltage calculated because there are two dc sources at the second level.

$\left(\frac{D_{f}+D_{a}}{2}\right) \cdot 3 n$

If six step sinus signals are compared with two triangles according to proposed modulation technique at the Matlab Simulink as shown in Fig. 5, SSPWMs are produced for six switches as in Fig. 6.

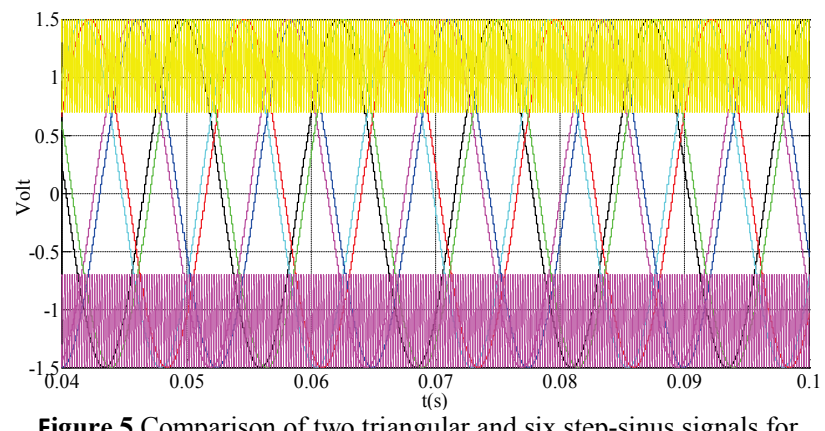

Figure 5 Comparison of two triangular and six step-sinus signals for PWM
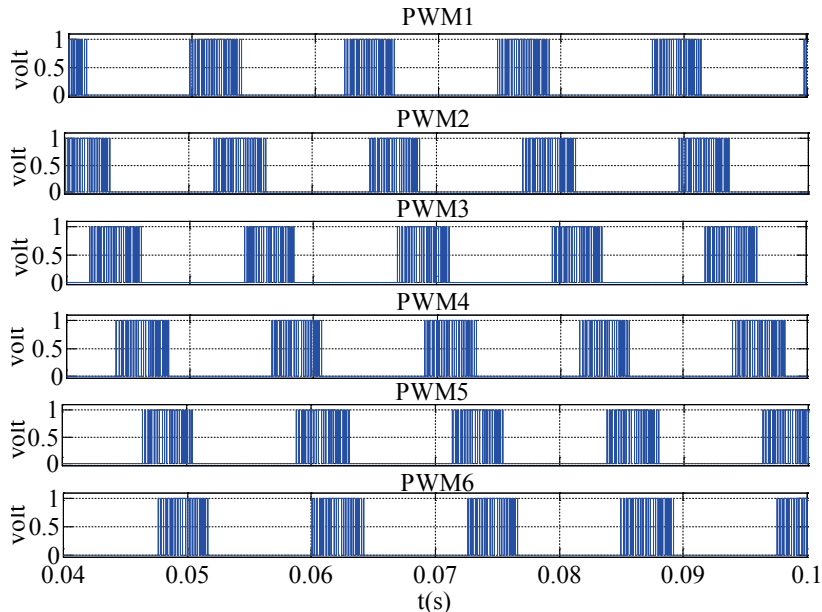

Figure 6 PWMs for switches

The Mathematical equations of the DC/AC multilevel Inverter in Fig. 1 are formed according to six PWMs given in Fig. 6. There are three-phases as abc. $L_{a}=L_{b}=$ $L_{c}=L, R=R_{a}=R_{b}=R_{c} . R$ and $L$ loads are connected as star for every phase. Sources voltage is $V=V_{d c}$. Threephase inverter circuit has switches as six MOSFETs and twelve IGBTs. These switches are operating in different groups in succession. Therefore, a $360^{\circ}$ sinus wave is created with $60^{\circ}$ switching angles. Phase voltages are obtained after three phase multilevel inverter performed as $360^{\circ}$. Alternating voltage $\left(V_{a c}\right)$ value is calculated by adding total switching pulse widths as Eq. (4) on period of $T / 2$. After that, mathematical equation is obtained for phase alternating voltage as Eq. (5).

$$
\frac{\left(\frac{D_{f}+D_{a}}{2}\right) \cdot 4 n \cdot V_{d c}}{\frac{T}{2}}=\left(\frac{D_{f}+D_{a}}{T}\right) \cdot 4 n \cdot V_{d c}
$$

Value of converted voltage is found while switch is OF as Eq. (6) on period of $T / 2$. According to this, mathematical equation is created for phase alternating voltage as Eq. (7). $D_{a}$ is $3 a ; D_{f}$ is $a$, step vertical size is $b . V_{d c}$ is direct voltage.

$3[b-a+b-3 a+\cdots+b-(n-1) a]=3 n b-6 \sum_{a=1}^{n / 2}(2 a-1)$, 


$$
\begin{aligned}
& 6\left[\left(\frac{n}{2} b\right)-\frac{n}{2} \cdot \frac{a+(n-1) a}{2}\right]=3 n \cdot\left(\frac{2 b-a n}{2}\right) \\
& V_{a c}=V_{d c}-2 n \cdot\left(\frac{2 b-a n}{T}\right) \cdot V_{d c}+2 V_{d c}-n \cdot\left(\frac{2 b-a n}{T}\right) \cdot 2 V_{d c}
\end{aligned}
$$

Although some mathematical equations are formed for engineering studies [20], mathematical equations are formed for multilevel inverter in open loop control.

If differential of equation voltage on $R$ and $L$ loads is used to create new mathematical equation, Eq. (9) and Eq. (10) are formed. When total switching pulse width of alternating voltage is calculated according to switching duty cycles which is values of $a$, Eq. (9) is formed. When total switching pulse widths of alternating voltage calculated according to switching values of $b$ and values of $a$, Eq. (9) is formed

$$
\begin{aligned}
& \left(\frac{D_{f}+D_{a}}{T}\right) \cdot 4 n \cdot V_{d c}=\frac{\mathrm{d} i}{\mathrm{~d} t} L+i R=V_{a c} \\
& 3 V_{d c}-4 n \cdot\left(\frac{2 b-a n}{T}\right) \cdot V_{d c}=\frac{\mathrm{d} i}{\mathrm{~d} t} L+i R=V_{a c}
\end{aligned}
$$

Differential equations of current can be calculated as Eq. (11) and Eq. (12).

$$
\begin{aligned}
& \left(\frac{D_{f}+D_{a}}{T L_{a}}\right) \cdot 4 n \cdot V_{d c}-\frac{i R}{L}=\frac{\mathrm{d} i}{\mathrm{~d} t}, \\
& \frac{3 V_{d c}}{L}-4 n \cdot\left(\frac{2 b-a n}{T L}\right) \cdot V_{d c}-\frac{i R}{L}=\frac{\mathrm{d} i}{\mathrm{~d} t} .
\end{aligned}
$$

$Z_{a}=R_{a}+j 2 \pi f L_{a}$. If mathematical equations are formed on $0^{\circ} \div 60^{\circ}$ and $120^{\circ} \div 180^{\circ}$ of switching time for alternating voltage, I1-M1 are ON. I2-I3-I4-M0 are OFF. If mathematical equations are formed for $60^{\circ} \div 120^{\circ}$ of switching time, I2-M1 are ON. I1,-I3-I4-M0 are OFF. After that, differential equation is formed from current and voltage equations for a phase as Eq. (11).

$$
\frac{3 V_{d c}}{L_{a}}-4 n \cdot\left(\frac{2 b-a n}{T L_{a}}\right) \cdot V_{d c}-\frac{i_{a} R_{a}}{L_{a}}=\frac{\mathrm{d} i_{a}}{\mathrm{~d} t} .
$$

$Z_{b}=R_{b}+j 2 \pi f L_{b}$. If mathematical equations are formed for alternating voltage on $60^{\circ} \div 120^{\circ}$ and $180^{\circ} \div 240^{\circ}$ of switching time, I5-M3 are ON. I6,-I7-I8-M2 are OFF. When mathematical equations are formed for $120^{\circ} \div 180^{\circ}$ degree switching time, I6-M3 are ON. I5,-I7-I8-M2 are OFF. New equation of $b$ phase is obtained from current and voltage equations as Eq. (12).

$\frac{3 V_{d c}}{L_{a}}-4 n \cdot\left(\frac{2 b-a n}{T L_{a}}\right) \cdot V_{d c}-\frac{i_{b} R_{b}}{L_{b}}=\frac{\mathrm{d} i_{b}}{\mathrm{~d} t}$.

$Z_{c}=R_{c}+j 2 \pi f L_{c}$. While mathematical equations are created for alternating voltage on $120^{\circ} \div 180^{\circ}$ and $240^{\circ} \div$ $300^{\circ}$ of switching time, I9-M5 are ON. I10,-I11-I12-M4 are OFF. If mathematical equations are formed for $180^{\circ} \div$ $240^{\circ}$ of switching time, I10-M2 are ON. I9,-I11-I2-M4 are OFF. New equation for $\mathrm{c}$ phase is obtained from current and voltage equations as Eq. (13).

$$
\frac{3 V_{d c}}{L_{c}}-4 n \cdot\left(\frac{2 b-a n}{T L_{c}}\right) \cdot V_{d c}-\frac{i_{c} R_{c}}{L_{c}}=\frac{\mathrm{d} i_{c}}{\mathrm{~d} t}
$$

Matrix form is created from Eq. (11), Eq. (12), and Eq. (13) as Eq. (14). Arranged duty cycles of SSPWM can provide new mathematical model which forms with linear mathematical calculation and differential equations while considering level dc voltage on load.

$$
\begin{aligned}
& {\left[\begin{array}{c}
\frac{\mathrm{d} i_{a}}{\mathrm{~d} t} \\
\mathrm{~d} i_{b} \\
\frac{\mathrm{d} t}{\mathrm{~d} i_{c}} \\
\mathrm{~d} t
\end{array}\right]=\left[\begin{array}{ccc}
-I_{a} R_{a}+V_{d c} & 0 & 0 \\
0 & -I_{b} R_{b}+V_{d c} & 0 \\
0 & 0 & -I_{c} R_{c}+V_{d c}
\end{array}\right]\left\{\begin{array}{c}
\frac{3}{L_{a}} \\
\frac{3}{L_{b}} \\
\frac{3}{L_{c}}
\end{array}\right\}-} \\
& -\left[\begin{array}{ccc}
4 n \cdot\left(\frac{2 b-a n}{T L_{a}}\right) & 0 & 0 \\
0 & 4 n \cdot\left(\frac{2 b-a n}{T L_{b}}\right) & 0 \\
0 & 0 & 4 n \cdot\left(\frac{2 b-a n}{T L_{c}}\right)
\end{array}\right] \cdot\left[\begin{array}{c}
V_{d c} \\
V d c \\
V d c
\end{array}\right] .
\end{aligned}
$$

\section{Inverter simulation}

Three phase multilevel inverter of simulation model is shown in Fig. 1. SSPWM multilevel inverter according to new approach is compared with SPWM controlling conventional inverter topology, which is traditional model with six switches. From I1 to I12 there are twelve IGBT switches, MOSFETs are from M0 to M5 for proposed inverter in Fig. 1. If SSPWM controlling multilevel inverter is operating on $R$ and $L$ loads that are $1 \mathrm{ohm}$ and 0.08 Henry at the Matlab Simulink, phase currents which are $I_{c}$, and $I_{b}, I_{c}$ are created as in Fig. 7. If SPWM controlling common three phase inverter is running ohmic and inductive loads at the Matlab Simulink, phase currents are as in Fig. 8.

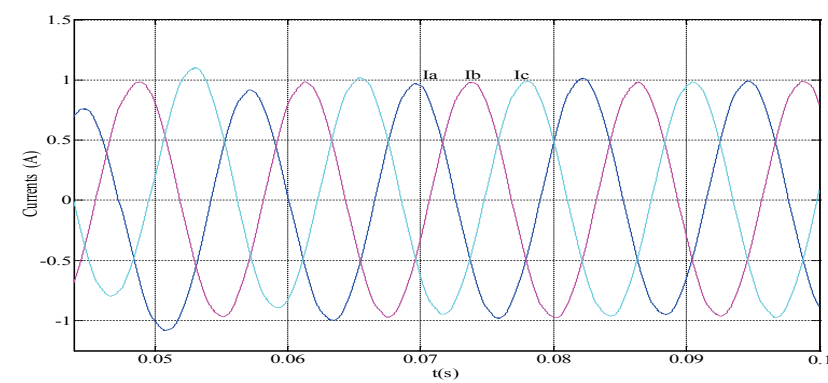

Figure 7 Phase currents of $R$ and $L$ loads according to SSPWM

When SSPWM controlling multilevel inverter performs loads, stable alternating current is obtained as sinus shape in Fig. 7 while SPWM controlling common inverter creates unstable alternating currents in Fig. 8. Proposed inverter forms three phase voltages as 4-level in Fig. 9. SSPWM technique achieves good performance. 


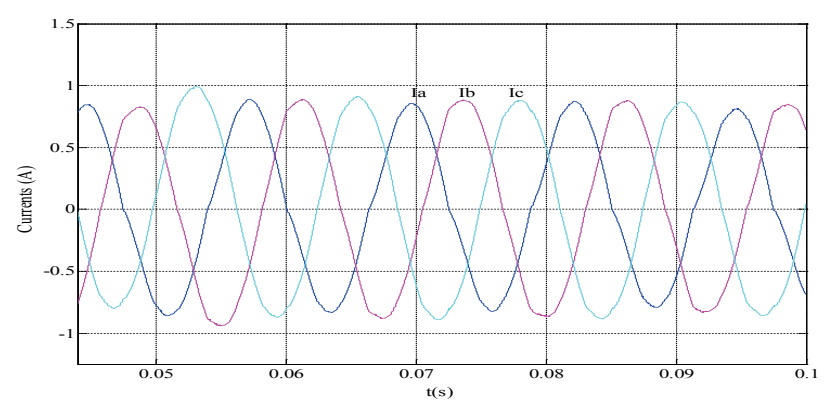

Figure 8 Phase currents of $R$ and $L$ loads according to SPWM
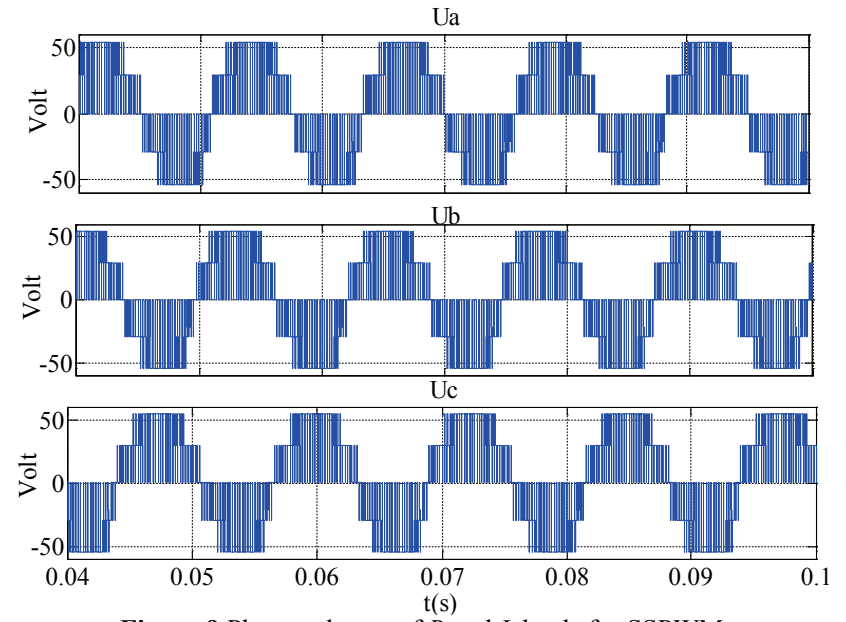

Figure 9 Phase voltages of $R$ and $L$ loads for SSPWM

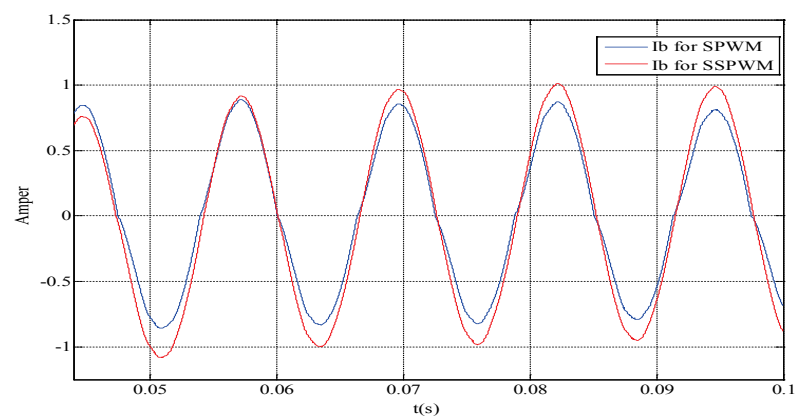

Figure $10 I_{b}$ current of SSPWM Compared with $I_{b}$ current of SPWM

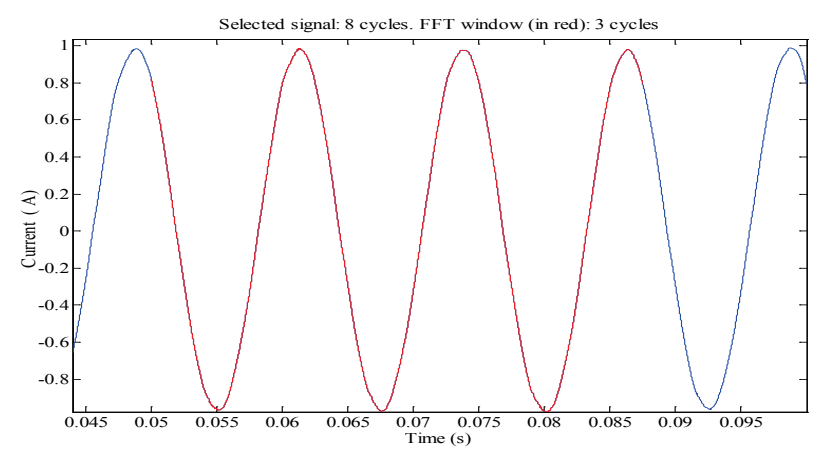

Figure 11 Current for SSPWM controlling inverter

When SSPWM multilevel inverter is driven on loads, inverter provides alternating currents as sinus shape for $I_{b}$ in Fig. 10 while PWM controlling common inverter does not provide alternating currents as sinus shape while comparing proposed inverter. Therefore, created SSPWM technique achieves good performance. $I_{b}$ Current harmonic distortion is shown in Fig. 12 while SSPWM controlling inverter creating $I b$ current is shown in Fig. 11. $I_{b}$ Current harmonic distortion is shown in Fig. 14 while common SPWM controlling inverter created current is shown in Fig. 13.

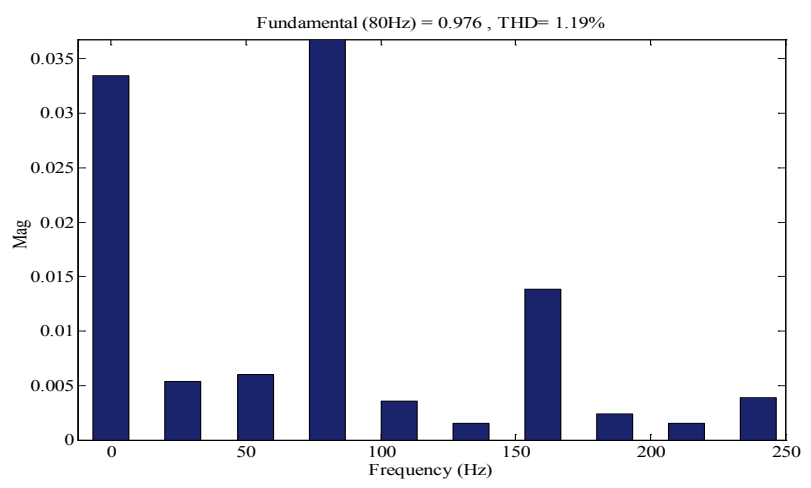

Figure 12 Current harmonic distortion of SSPWM controlling inverter created current

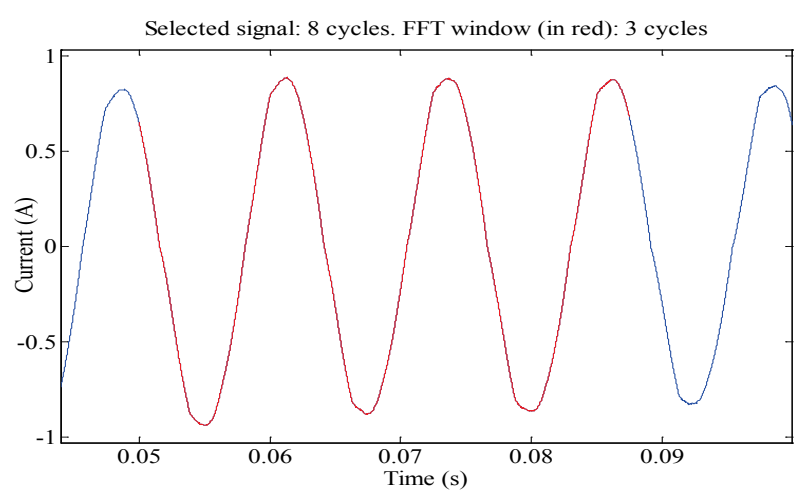

Figure 13 Common PWM controlling inverter creating current

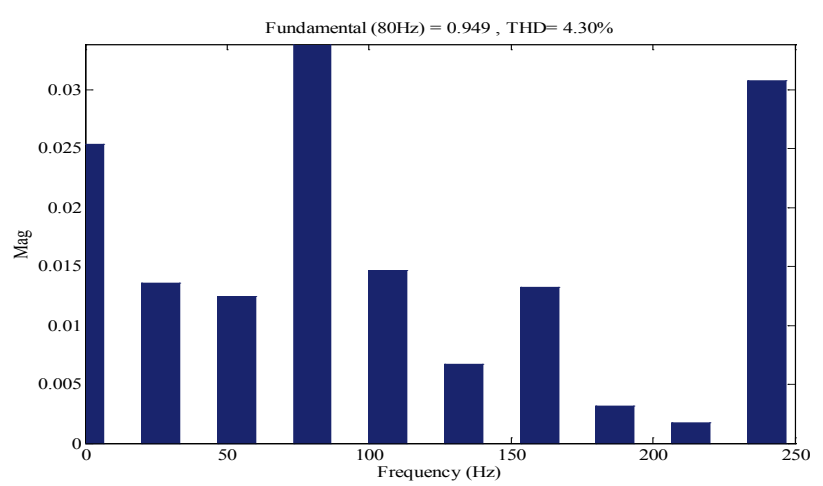

Figure 14 Current harmonic distortion of common PWM controlling inverter created current

Used step sinus pulse width modulation provides Harmonic distortion at the low level if optimal performances are taken. Harmonic distortion is $1,19 \%$ as shown in Fig. 15. This result is very acceptable because $1,19 \%$ harmonic distortion is smaller than $4 \%$. Harmonic distortion for traditional modulation method has to show low level value if demanded results are taken. The distortion is $4,30 \%$. This result does not ensure demanded level because $4,30 \%$ harmonic distortion is bigger than $4 \%$. An arranged Duty cycle of SSPWM as $1 / 2 \times(10 \mathrm{a}, 14 \mathrm{a}, 18 \mathrm{a}, 22 \mathrm{a}$, and 26a) and (10a, 14a, 18a, $22 \mathrm{a}$, and 26a) achieves optimal output results with reducing nonlinear effects of harmonic. Harmonic distortions of loads according to different frequencies are given in Tab. 1 and Fig. 15. 
Table 1 Harmonic effect according to frequencies

\begin{tabular}{|c|c|c|c|}
\hline \multicolumn{2}{|c|}{ SSPWMIMPLEMENTED } & \multicolumn{2}{|c|}{ SPWMIMPLEMENTED } \\
\hline Frequencies, Hz & THD & Frequencies, Hz & THD \\
\hline 250 & 1,35 & 250 & 4,3 \\
\hline 220 & 1,25 & 220 & 4,1 \\
\hline 180 & 1,19 & 180 & 3,70 \\
\hline 160 & 1,1 & 160 & 3,50 \\
\hline 140 & 0,99 & 140 & 3,43 \\
\hline 120 & 0,95 & 120 & 3,3 \\
\hline 100 & 0,93 & 100 & 3,1 \\
\hline 80 & 0,89 & 80 & 3 \\
\hline 60 & 0,80 & 60 & 2,92 \\
\hline 50 & 0,76 & 50 & 2,83 \\
\hline
\end{tabular}

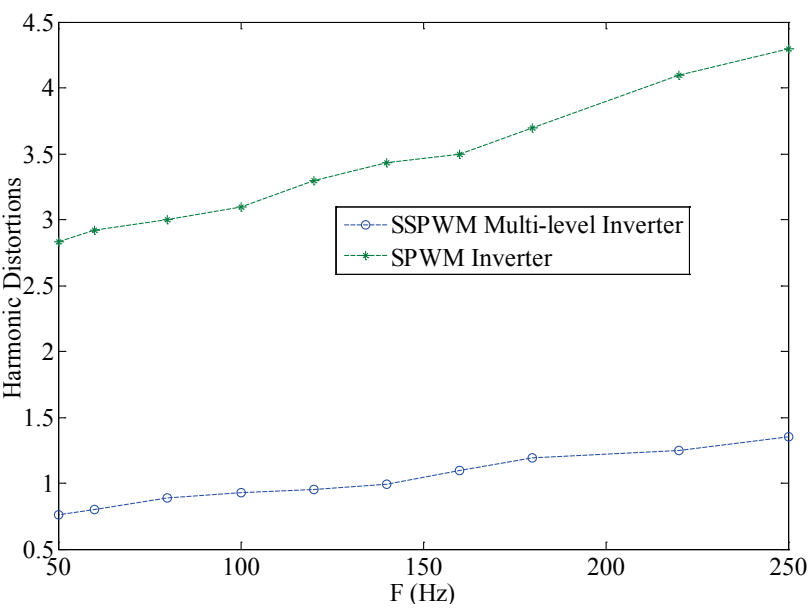

Figure 15 Current harmonic distortions of SSPWM and SPWM controlling inverter on frequencies

On frequencies, harmonic distortions of current for SSPWM and SPWM controlling inverter are shown in Fig. 15. Current harmonic distortions of SPWM controlling PWM decline from $4,3 \%$ to $2,83 \%$ between $50 \mathrm{~Hz}$ and $250 \mathrm{~Hz}$ while harmonic distortions of SSPWM controlling PWM decrease from $1,35 \%$ to $0,76 \%$ between $50 \mathrm{~Hz}$ and $250 \mathrm{~Hz}$.

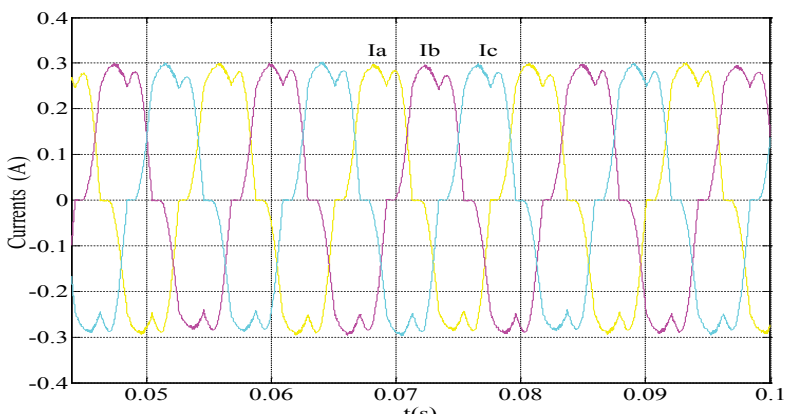

Figure 16 SSPWM controlling inverter creating currents for 0,3 modulation index

Modulation indexes affect currents of inverter running loads and harmonic distortions. SSPWM controlling inverter creates currents for 0,3 modulation index as shown in Fig. 16 while harmonic distortion of current is given in Fig. 17.

Currents of SSPWM inverter running loads are 0,976 ampere for 0,9 modulation index in Fig. 8 while currents of SSPWM inverter running loads are 0,2996 ampere for 0,3 modulation index in Fig. 16.
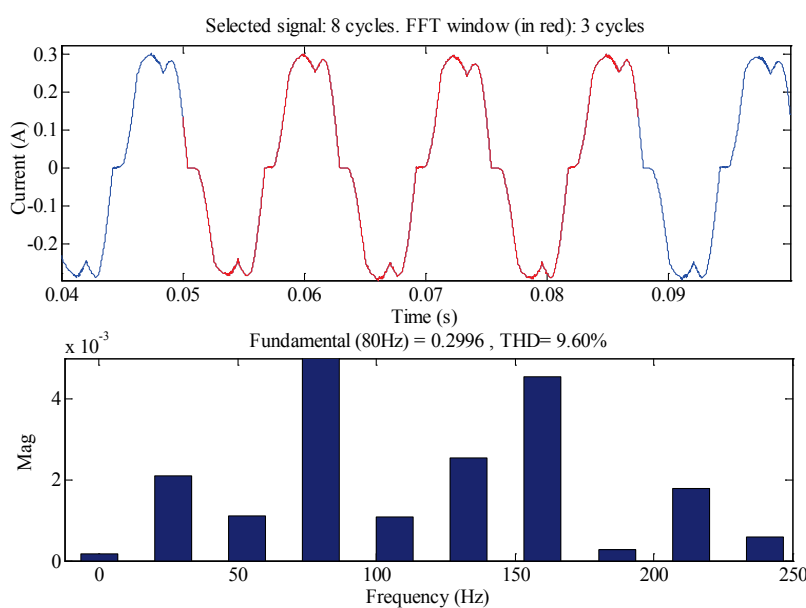

Figure 17 Harmonic distortion of SSPWM inverter running load for 0,3 modulation index

Harmonic distortion of SSPWM inverter for current is 1,19 for 0,9 modulation index in Fig. 13 while currents harmonic distortion of inverter running loads is 9,60 for 0,3 modulation index in Fig. 17.

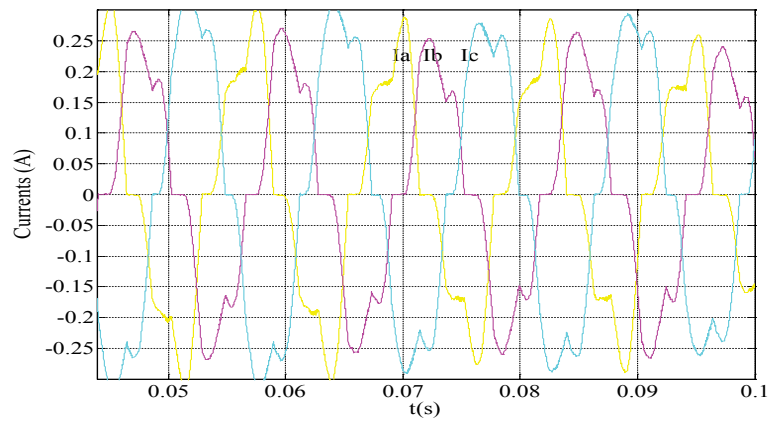

Figure18 SPWM controlling inverter creating currents for 0,3 modulation index

Currents of inverter running loads are 0,949 ampere for 0,9 modulation index in Fig. 7 while currents of inverter running loads are 0,2269 ampere for 0,3 modulation index in Fig. 18.
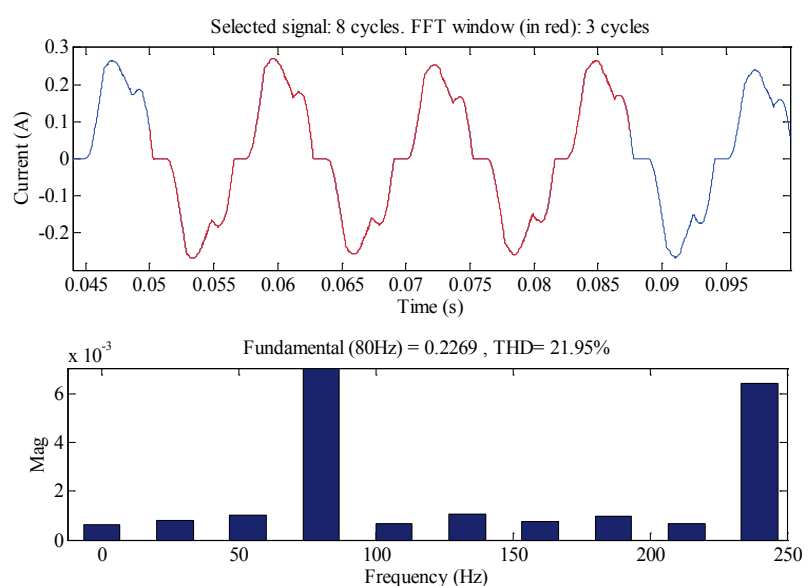

Figure 19 Harmonic distortion of traditional PWM inverter running load on 0,3 modulation index

SPWM controlling inverter creates currents for 0,3 modulation index as shown while harmonic distortion of current is given in Fig. 20.

Current harmonic distortion of SSPWM inverter running load is $4,30 \%$ for 0,95 modulation index in Fig. 
15 while currents harmonic distortion of inverter running loads is $21,95 \%$ for 0,3 modulation index in Fig. 20.

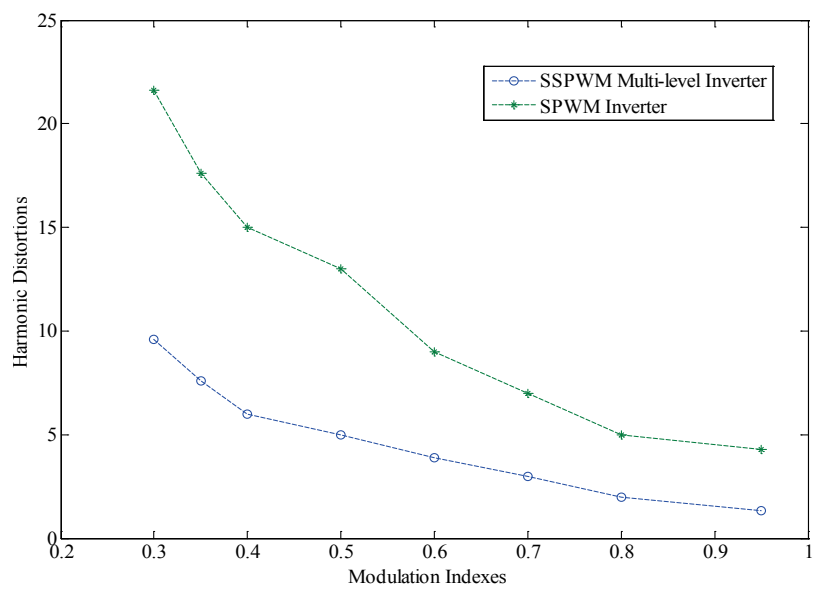

Figure 20 Harmonic distortions for SSPWM and SPWM controlling inverter creating current on modulation indexes

Current harmonic distortions of SSPWM and SPWM controlling inverter on modulation indexes are shown in Fig. 20. For $250 \mathrm{~Hz}$, current harmonic distortions of SPWM controlling inverter decrease from $22,95 \%$ to 4,3 $\%$ between 0,3 modulation index and 0.95 modulation index while current harmonic distortions of SSPWM controlling inverter decrease from $9,60 \%$ to $1,35 \%$ between 0,3 and 0,95 modulation indexes. SSPWM has higher performance than common SPWM when SSPWM and SPWM controlling inverter are observed in used modulation indexes and frequencies.

\section{Conclusion}

New equations are described with proposed modulation method (SSPWM) for multi-level inverter. Arranged duty cycles of SSPWM could provide different mathematical operation by considering source sections for inverter level on loads voltages. SSPWM controlling the inverter running $R$ and $L$ loads is simulated at the Matlab Simulink. SSPWM multi-level inverter and SPWM controlling inverter creating currents on modulation indexes are investigated for harmonic distortions. Simulation results show that the proposed inverter has optimal results while traditional PWM inverter does not obtain accepted level on harmonic distortion. The distortion for step sinus pulse width modulation is 1,35\% while harmonic distortion for traditional modulation method is $4,30 \%$ for $250 \mathrm{~Hz}$. SPWM produces unbalanced alternating voltage while increasing nonlinear effect on loads. The SSPWM provided alternating voltage has just sinus shape. Current harmonic distortions of SPWM controlling inverter decrease from $21,95 \%$ to $2,83 \%$ between 0,3 modulation index and 0,95 modulation index while Current harmonic distortions of SSPWM controlling inverter decreased from $9,60 \%$ to $1,35 \%$ between 0,3 modulation index and 0,95 modulation index.

Results demonstrate multi-level inverter with step sinus pulse modulation and mathematical model provide high performance. So, satisfactory results are obtained in the study.

\section{References}

[1] Peng, F. Z.; Lai, J. S.; McKeever, J. W.; Van Coevering, J. A multilevel voltage-source inverter with separate DC sources for static var generation. // IEEE Transactions on Industry Applications. 32, 5(1996), pp. 1130-1138. DOI: 10.1109/28.536875

[2] Twining, E.; Holmes, D. G. Grid current regulation of a three-phase voltage source inverter with an LCL input filter. // IEEE Transactions on Power Electronics, 18(3), (2003), pp. 888-895. DOI: 10.1109/TPEL.2003.810838

[3] Peng, F. Z. A generalized multilevel inverter topology with self voltage balancing. // IEEE Transactions on industry applications. $37, \quad 2(2001), \quad$ pp. 611-618. DOI: 10.1109/28.913728

[4] Taghvaie, A.; Adabi, J.; Rezanejad, M. Circuit Topology and Operation of a Step-Up Multilevel Inverter with a Single DC Source. // IEEE Transactions on Industrial Electronics. $63,11(2016), \quad$ pp. 6643-6652. DOI: 10.1109/TIE.2016.2585568

[5] Liu, J.; Sun, Y.; Li, Y.; Fu, C. Theoretical harmonic analysis of cascaded H-bridge inverter under hybrid pulse width multilevel modulation. // IET Power Electronics. 9, 14(2016), pp. 2714-2722. DOI: 10.1049/iet-pel.2016.0163

[6] Can, E. Novel high multilevel inverters investigated on simulation. // Electrical Engineering. (2016), pp. 1-6. DOI: 10.1007/s00202-016-0396-z

[7] Can, E.; Sayan, H. H. A novel SSPWM controlling inverter running nonlinear device. // Electrical Engineering. (2016), pp. 1-8. DOI: $10.1007 / \mathrm{s} 00202-016-0480-4$

[8] Ho, Anh-V.; and Tae-Won C. Topologies of ActiveSwitched Quasi-Z-source Inverters with High-Boost Capability. // Journal of Power Electronics. 16, 5(2016), pp. 1716-1724. DOI: 10.6113/JPE.2016.16.5.1716

[9] Runghimmawan, T. Design and Implementation Multilevel Inverter for 3 phase Induction Motor Speed Control with RBM Chopper Technique embedded on FPGA. // Power System Technology. 2006.

[10] Can, E.; Sayan, H. H. Sspwm Three Phase Inverter Design And Experimented On Unbalanced Loads. // Tehnicki Vjesnik-Technical Gazette. 23, 5(2016), pp. 1239-1244. DOI: $10.17559 / \mathrm{TV}-20150730222021$

[11] Harish, S.; Rao, G. R.; Kiran, S. R. Three phase multi level inverter for high power applications. // Electrical, Electronics, and Optimization Techniques (ICEEOT), International Conference on IEEE. (2016, March), pp. $4092-4096$

[12] Saavedra, H.; Riba, J.-R.; Romeral, L. Detection of Interturn Faults in Five-Phase Permanent Magnet Synchronous Motors. // Advances in Electrical and Computer Engineering. 14, 4(2014), pp. 49-54. DOI: 10.4316/AECE.2014.04008

[13] Livadaru, L.; Simion, A.; Munteanu, A.; Cojan, M.; Dabija, O. Dual Cage High Power Induction Motor with Direct Start-up. Design and FEM Analysis. // Advances in Electrical and Computer Engineering. 13, 2(2013), pp. 5558. DOI: 10.4316/AECE.2013.02009

[14] Demirdelen, T.; Kayaalp, R. I.; Tumay, M. A Modular Cascaded Multilevel Inverter Based Shunt Hybrid Active Power Filter for Selective Harmonic and Reactive Power Compensation under Distorted/Unbalanced Grid Voltage Conditions. // Engineering, Technology \& Applied Science Research. 6, 5(2016), pp. 1133-1138.

[15] Xu, S.; Ji, Z. A Study of the SPWM High-Frequency Harmonic Circulating Currents in Modular Inverters. // Journal of Power Electronics. 16, 6(2016), pp. 2119-2128. DOI: 10.6113/JPE.2016.16.6.2119

[16] Emadi, A.; Afrakhte, H.; Sadeh, J. Fast active islanding detection method based on second harmonic drifting for inverter-based distributed generation. // IET Generation, 
Transmission \& Distribution. 10, 14(2016), pp. 3470-3480. DOI: 10.1049/iet-gtd.2016.0089

[17] Giribabu, D.; Vardhan, R. H.; Prasad, R. R. Multi level inverter fed indirect vector control of induction motor using type 2 fuzzy logic controller. // Electrical, Electronics, and Optimization Techniques (ICEEOT), International Conference on IEEE. (2016, March), pp. 2605-2610.

[18] Xavier, L. S.; Cupertino, A. F.; de Resende, J. T; Mendes, V. F.; Pereira, H. A. Adaptive current control strategy for harmonic compensation in single-phase solar inverters. // Electric Power Systems Research. 142, (2017), pp. 84-95. DOI: 10.1016/j.epsr.2016.08.040

[19] Can, E.; Sayan, H. H. PID and fuzzy controlling three phase asynchronous machine by low level DC source three phase inverter/PID i neizrazito upravljanje trofaznim asinhronim motorom pomocu trofaznog izmjenjivaca slabe istosmjerne struje. // Tehnicki Vjesnik-Technical Gazette. 23, 3(2016), pp. 753-761.

[20] Karchevskii, E.; M., Beilina L.; Spiridonov, A. O., ; Repina, A. I. Reconstruction of dielectric constants of multi-layered optical fibers using propagation constants measurements. // (2015), arXiv preprint arXiv:1512.06764.

\section{Authors' addresses}

\section{Asst. Prof. Dr. Erol Can}

Department of Aircraft Airframe and Power Plant,

School of Civil Aviation, Erzincan University,

Erzincan, Turkey

E-mail: can_e@hotmail.com

\section{Asst. Prof. Dr. H. Hüseyin Sayan}

Department of Electrical and Electronics Engineering,

Faculty of Technology, Gazi University,

Ankara, Turkey

E-mail: hsayan@gazi.edu.tr 